\title{
Antithrombotic therapy in acute ischemic stroke patients with atrial fibrillation
}

\section{Antitrombotična terapija kod pacijenata sa akutnim ishemijskim moždanim udarom i atrijalnom fibrilacijom}

\author{
Višnja Pađen ${ }^{1}$, Ljiljana Beslać Bumbaširević
}

\author{
${ }^{1}$ Klinika za neurologiju, Klinički Centar Srbije \\ ${ }^{2}$ Klinika za neurologiju, Klinički Centar Srbije, Medicinski fakultet Univerziteta u Beogradu
}

Kontakt: visnja.padjen@hotmail.com

\section{Sažetak}

Atrijalna fibrilacija (AF) predstavlja nezavisni faktor koji pet puta povećava rizik od nastanka akutnog ishemijskog moždanog udara (AIMU). Ona predstavlja i značajan prediktor lošeg ishoda AIMU. Cilj ovog članka je da se analizira aktuelni pristup u prevenciji i lečenju AIMU udruženih sa AF.

U prevenciji AIMU kod bolesnika sa AF preporučuje se oralna antikoagulantna terapija (OAC). Ona podrazumeva ili antagoniste vitamina $\mathrm{K}$ (VKAs) ili nove oralne antikoagulanse (NOAC). U primarnoj prevenciji AIMU, korišćenjem skorova za stratifikaciju faktora rizika, potrebno je identifikovati AF bolesnike sa „niskim rizikom“ kojima nije potrebna nikakva antitrombotična terapija. Posledično, svim ostalim bolesnicima sa AF indikovano je uvođenje OAC. U sekundarnoj prevenciji AIMU indikovano je uvođenje OAC za sve bolesnike sa AF. Procenu rizika od nastanka krvarenja treba vršiti u cilju uticaja na one faktore rizika koji mogu da budu modifikovani. Intravenska trombolitička terapija (IVT) verovatno može da se bezbedno primenjuje kod bolesnika koji su prethodno bili na terapiji VKAs ukoliko im je vrednost međunarodnog normalizovanog odnosa (engl. International normalized ratio, INR) manja od 1.7, iako je tada rizik od pojave krvarenja malo viši. Podaci o primeni IVT kod bolesnika sa NOAC su oskudni, ali određeni parametri koagulacije mogu da pomognu u cilju identifikacije onih bolesnika koji bi bili pogodni za primenu trombolitičke terapije.

Prevencija AIMU kod bolesnika sa AF je od ključnog značaja i za njeno sprovođenje se savetuje upotreba OAC. U akutnoj fazi AIMU, ukoliko su bolesnici adekvatno antikoagulisani primenom bilo kog OAC, kontraindikovana je primena IVT. Njena upotreba se može razmatrati u određenim slučajevima kada je antikoagulisanost nedovoljna.

Ključne reči: atrijalna fibrilacija, akutni ishemijski moždani udar, prevencija, ishod, tromboliza

\section{Abstract}

Atrial fibrillation (AF) is an independent risk factor that increases the risk of acute ischemic stroke by five-fold. In addition, it is also a significant predictor of stroke's poor outcome. The aim of this article was to provide an overview on current approach in AF associated stroke prevention and treatment.

Oral anticoagulant therapy (OAC) is recommended for stroke prevention in AF patients. This includes either vitamin $\mathrm{K}$ antagonists (VKAs) or novel oral anticoagulants (NOACs). In primary prevention, by using risk stratification schemes, clinicians should identify low-risk AF patients who do not require antithrombotic therapy; all others are indicated for OAC. For secondary stroke prevention all AF patients should be offered OAC. The assessment of bleeding risk should also be performed in order to influence modifiable risk factors for bleeding. Intravenous thrombolysis (IVT) can probably be administrated safely in patients given VKAs if the international normalised ratio is less than 1.7, although bleeding risk is slightly raised. Data regarding safety of IVT used in patients on NOAC are very scarce, however, some coagulation parameters could help to identify those patients who might be eligible for thrombolysis.

Stroke prevention is central to the management of AF. The use of OAC is recommended for stroke prevention. In the acute stroke phase, if patients are fully anticoagulated, by any medication, then IVT is contraindicated. However, it may be considered in some circumstances if the level of anticoagulation is subtherapeutic.

Key words: atrial fibrillation, stroke, prevention, outcomes, thrombolysis 


\section{Introduction}

Atrial fibrillation (AF) is the most prevalent sustained heart rhythm disorder, associated with severe consequences that include heart failure, stroke, reduced quality of life, poor mental health and death. (1) Around 2\% of the world's population has AF and it is predicted that its prevalence will rise for over 2.5 times by 2050 . (2-4) The average age of patients with this condition is steadily rising, currently averaging between 75 and 85 years. (5)

About 20 years ago, the Framingham study has pointed out $\mathrm{AF}$ as an independent risk factor for the ischemic stroke. This study has shown that individuals with AF are five times more likely to have a stroke, in comparison with those without AF. This incidence is even higher in conjunction with hypertension or congestive heart failure. (6) Subsequent studies have confirmed AF to be an independent risk factor for stroke, by estimating that, overall, it increases the stroke risk by 5-fold. (7) AF is estimated to be responsible for approximately $15-20 \%$ of all strokes. (8) Moreover, AF is the most important single cause of ischemic stroke in the elderly. (9) AF-associated strokes are more severe with a higher mortality rate. (10) Furthermore, they are more likely to lead to disability (11), to increase costs (12) and extended hospital care, compared to non-AF strokes. (13)

\section{Stroke risk factors and Risk stratification schemes}

Most common reported AF related stroke risk factors are: heart failure, hypertension, diabetes, age and prior stroke/transient ischemic attack (TIA). $(14,15)$ Moreover, various stroke risk factors in AF have been used to formulate several stroke risk prediction tools to help risk stratify patients with AF. (16) Most commonly used are CHADS2 and CHA2DS2-VASc score (table 1).

CHADS2 score value of 0 represents low risk of stroke, CHADS2 score $=1$ represents moderate risk, while in the case when the CHADS2 score $\geq 2$ it is a high risk for throboembolic events. (17) CHA2DS2-VASc score value of 0 represents low risk for thromboembolic event, CHA2DS2-VASc score $=1$ represents moderate risk, while CHA2DS2-VASc score $\geq 2$ is a high risk. (17). Current recommendations state that all patients with CHADS2 and CHA2DS2-VASc score $\geq 2$ are indicated for oral anticoagulant therapy (OAC), while in cases of moderate risk therapy can be: OAC, aspirin or none (5, 17). However, these stratification schemes, that are based on clinical risk factors, have been showing weak or modest predictive value for identifying high risk patients. (18) It is argued that the most important limitation, es-
Table 1. Prevention stratification schemes for thromboembolic risk

\begin{tabular}{ll}
\hline $\mathrm{CHADS}_{2}$ & Score \\
\hline Congestive heart failure & 1 \\
Hypertension & 1
\end{tabular}

Age $>75$ years

Diabetes mellitus

1

Stroke/TIA

2

\begin{tabular}{ll}
\hline CHA $_{2}$ DS $_{2}$-VASc & Score \\
\hline Congestive heart failure & 1 \\
\hline Hypertension & 1 \\
\hline Age $>75$ years & 2 \\
\hline Diabetes mellitus & 1 \\
\hline Stroke/TIA & 2 \\
\hline Vascular disease & 1 \\
\hline Age 65-74 years & 1 \\
\hline Sex (female gender) & 1 \\
\hline
\end{tabular}

pecially for CHADS2 score, is the fact that it classifies a large portion of patients into the intermediate risk category (C statistic, approximately 0.6$)$. $(16,19)$ Nevertheless, CHA2DS2-VASc score has been shown to have particular value in identifying low-risk patients who do not need antithrombotic therapy. $(20,21)$ Hence, more recent guidelines have moved toward initial identification of low-risk patients first (because these patients do not need any antithrombotic therapy), rather than focus on identifying high-risk patients. (16)

In addition to stroke risk assessment, it is important to evaluate bleeding risk in AF patients, especially cases in which thromboprophylaxis is being considered. (22) Various scores have been proposed, but only HASBLED score has been validated in multiple independent cohorts (table 2). 
Table 2. Prevention stratification schemes for bleeding risk

\begin{tabular}{ll}
\hline HAS-BLED & Score \\
\hline Hypertension & 1 \\
\hline Abnormal renal/liver function & 1 or 2 \\
\hline Stroke & 1 \\
\hline Bleeding & 1 \\
\hline Labile INR & 1 \\
\hline Elderly (>65 years) & 1 \\
\hline Drugs or alcohol intake & 1 or 2 \\
\hline
\end{tabular}

HAS-BLED score has been shown to be predictive of intracranial haemorrhage risk, to predict bleeding during bridging therapy, (23) as well as in use of novel oral anticoagulants (NOACs) (16). HAS-BLED score values $\geq 3$ indicate that there is a high risk of bleeding (17). However, a high HAS-BLED score is not a reason to withhold OAC, but it can be used to highlight patients' potential risk of bleeding and to point out to the need to focus on correcting the potentially reversible factors that contribute to bleeding (e.g. uncontrolled hypertension, excessive alcohol intake, labile INRs).

\section{AF diagnosing}

Diagnosing AF before first complications occur, is recognized as a priority for stroke prevention. (24) It is estimated that about one half of AF patients remain undetected, mainly because symptoms are considered to be unimportant. For many patients, a stroke is the first sign of underlying AF. $(25,26)$ Therefore, current guidelines recommend that, in patients aged 65 years or over, opportunistic screening for AF by pulse palpation, followed by recording of an ECG to verify diagnosis, should be considered for the early detection of AF. (5)

\section{Stroke prevention}

Studies have shown that the risk of stroke in AF patients is reduced by the use of antithrombotic therapy. (27) All major guidelines emphasize the role of OAC for prevention of AF-associated strokes.

Contrary to popular belief that aspirin is safer than warfarin, studies have shown that aspirin actually increases the risk of bleeding, particularly in the gastrointestinal tract. (28) Moreover, studies that have directly compared aspirin with warfarin in AF-associated stroke prevention have shown that the efficacy of stroke prevention with aspirin is weak, by reporting that warfarin is significantly superior, since it reduces the risk of stroke almost two times more compared to aspirin. (29) Consequently, current recommendation is that the use of antiplatelet therapy (as aspirin-clopidogrel combination therapy or-less effectively-aspirin monotherapy for those who cannot tolerate aspirin-clopidogrel combination therapy) for stroke prevention in AF should be limited only in cases of patients who cannot or refuse to take any form of OAC. (16)

Current recommendations are that thromboprophylaxis in AF patients can be obtained with vitamin $\mathrm{K}$ antagonists (VKA, e.g. warfarin) or a non-VKA oral anticoagulant (NOAC).

Vitamin $\mathrm{K}$ antagonists are associated with an absolute RR of $2.7 \%$ per year (number needed to treat, 37) for embolism in patients with no history of prior stroke (primary prevention) and $8.4 \%$ per year (number needed to treat, 12) for patients with a history of prior stroke (secondary prevention). (16) With VKAs, the quality of anticoagulation control is essential (as reflected by the time in therapeutic range [TTR], with a target INR of 2.0-3.0). However, studies have shown that the proportion of patients with AF treated with warfarin, in the primary stroke prevention, is about $54-61 \%,(30)$ and that these patients tend to have inefficient or unsafe warfarin levels in the blood of nearly half time. (31) Current estimations are that only $1 / 5$ of all AF patients actually receive adequate and effective anticoagulation at any point of time. (31)

The introduction of NOACs has changed the landscape in AF-stroke prevention in recent years. In contrast to VKAs, which block the formation of multiple active vitamin K-dependent coagulation factors (factors II, VII, IX and X), these drugs block the activity of one single step in coagulation. (5) NOACs consist of two groups of medications: the oral direct thrombin inhibitors (e.g. dabigatran) and oral factor Xa inhibitors (e.g., rivaroxaban, apixaban and edoxaban). None of NOACs so far tested in clinical trials have shown inferiority compared with VKAs, with better safety, consistently limiting the number of ICH. (5) Moreover, the use of these medications does not require INR monitoring. However, since there is still limited experience with these agents, the strict adherence to approved indications is recommended. There is insufficient evidence to recommend one NOAC over another, although some patients' characteristics, drug compliance, tolerability and cost may be important considerations in the choice of the agent. Compliance and adherence to treatment is crucial (dabigatran and apixaban have twice daily dose regimens). These drugs have a relatively short half-life, so patients would be left without 
any anticoagulation protection if more than one dose is missed. Furthermore, all of these drugs have a degree of renal excretion, especially dabigatran. Thus, assessment of renal function (by $\mathrm{CrCl}$ ) is mandatory. The NOACs do not require dose adjustment on the basis of a specific coagulation test (in contrast to the INR for VKAs). There are non-specific coagulation tests that can be used to check the presence of an anticoagulation effect. Studies have shown that for dabigatran, an activated partial thromboplastin time (aPTT) can be used although the correlation is not linear, particularly at higher concentrations. (5) Rivaroxaban prolongs the prothrombin time (PT) and this might be used as a rough estimate of an anticoagulation effect. (5) For the Factor Xa inhibitors a better anticoagulant estimate can be provided by an anti-Xa assay. (5) None of the novel OACs has a specific antidote, but the management of bleeding is considered to be largely supportive, given that these drugs have a relatively short half-life (5 to 17 hours).

\section{Intravenous thrombolysis in AF-associated strokes}

Intravenous thrombolysis (IVT) is the only approved therapy for the treatment of patients with acute ischemic stroke, within the time frame of 4.5 hours from the symptoms onset and it significantly increases the proportion of patients who are left without neurological deficit after 3 months. $(32,33)$ Indications of IVT are: (i) acute ischemic stroke symptoms with onset, or last well known time, clearly defined 4.5 hours before IVT will be given; (ii) an acute neurologic deficit expected to result in significant long-term disability; (iii) non-contrast CT showing no haemorrhage or well-established acute infarct. (32, 34-39) Data about efficacy of IVT in the treatment of AF-associated strokes is still scarce, since only few randomised controlled trials have analyzed this specific subpopulation, and have reported conflicting results: with a non-significant trend in favour of placebo in ECASS III (40), in favour of IVT in IST-3 (41) and no effect of the treatment in NINDS. (42) Observational studies have, in majority of cases, reported a benefit of IVT administration in AF-associated stroke patients. (43 - 46) Furthermore, data regarding the occurrence of symptomatic haemorrhagic transformation (sICH) in thrombolyzed patients with AF-associated stroke are also conflicting: some observational studies found no statistically significant difference in the occurrence of sICH, (47-50) while other studies (including 2 meta-analyzes) reported opposite results that the risk of sICH in these patients is higher. $(51,54)$ Moreover, as AF occurs in elderly patients, the prevalence of subclinical brain changes, associated with cognitive impairment or not, may pre- dispose to bleeding, such as white matter changes, silent infarcts or microbleeds, is high. (46) Another issue is the fact that, in practice, many AF patients cannot be treated with IVT because of on-going oral anticoagulation therapy with a baseline INR $>1.7$. Moreover, patients taking the NOACs may also present with an acute ischemic stroke. Current recommendations state that, in these cases, thrombolysis should only be initiated if the clinical history and a laboratory test reliably suggest the absence of an anticoagulant effect, or until at least two half-lives have elapsed since the most recent dose of the NOAC (in patients with normal renal function). (55)

\section{Conclusion}

In recent years, a substantial improvement has been registered in the field of prevention of AF-associated strokes. Current guidelines recommend early detection of $\mathrm{AF}$ in asymptomatic patients(especially older than 65 years), as well as identification of low risk patients (who do not need any antithrombotic therapy). Subsequently, patients with at least 1 additional stroke risk factor, as well as those with previous stroke/TIA should be offered with OAC (either VKAs or NOAC). IVT can probably be safely administered in patients on VKAs if the INR is less than 1.7, although bleeding risk is slightly raised. The challenge for clinicians evaluating and considering treatment options, for patients with acute ischemic stroke who are taking NOACs, is to determine the anticoagulant effect of these agents reliably and rapidly and to estimate the potential increased risk of symptomatic hemorrhage. Currently, almost no data are available for the safety of IVT use in these patients, however, some coagulation parameters could help to identify those patients who might be eligible for thrombolysis.

\section{References}

1. Stewart S, Hart CL, Hole DJ, et al. A population-based study of the long-term risks associated with atrial fibrillation: 20-year-follow-up of the Renfrew/Paisley study. Am J Med 2002; 113:359-64.

2. Kannel WB, Wolf PA, Benjamin EJ, et al. Prevalence, incidence and predisposing conditions for atrial fibrillation: population-based estimates. Am J Cardiol 1998; 82:2N-9N

3. Go AS, Hylek EM, Philips KA, et al. Prevalence of diagnosed atrial fibrillation in adults: national implications for rhythm management and stroke prevention: the AnTicoagulation and Risk Factors in Atrial Fibrillation (ATRIA) Study. JAMA 2001; 285(18):2370-5.

4. Miyasaka Y, Barnes ME, Gersh BJ, et al. Secular trends in incidence of atrial fibrillation in Olmsted County Minnesota, 1980 to 2000, and implications on the projections for future prevalence. Circulation 2006; 114:119-25. 
5. Camm AJ, Lip GY, De Caterina R, et al. 2012 focused update of the ESC Guidelines for the management of atrial fibrillation: an update of the 2010 ESC Guidelines for the management of atrial fibrillation--developed with the special contribution of the European Heart Rhythm Association. Europace. 2012; 14(10):1385-413.

6. Wolf PA, Abbott RD, Kannel WB. Atrial fibrillation as an independent risk factor for stroke: the Framingham Study. Stroke 1991; 22:983-988.

7. Benjamin EJ, Wolf PA, D’Agostino RB, et al. Impact of atrial fibrillation on the risk of death: the Framingham Heart Study. Circulation 1998; 98(10): 946-652.

8. Wolf PA, Abbott RD, Kannel WB. Atrial fibrillation a major contributor to stroke in the elderly. The Framingham Study. Arch Inter Med 1987; 147:1561-4.

9. Giralt-Steinhauer E, Cuadrado-Godiab E, Oisb A, et al. Comparison between CHADS2 and CHA2DS2-VASc score in a stroke cohort with atrial fibrillation. Eur J Neurol 2013; 20(4):623-8.

10. Gladstone DJ, Bui E, Fang J, et al. Potentially preventable strokes in high-risk patients with atrial fibrillation who are not adequately anticoagulated. Stroke 2009; 40:235-40.

11. Lamassa M, Di Carlo A, Pracucci G, et al. Characteristics, outcome and care of stroke associated with atrial fibrillation in Europe: data from a multicentre multinational hospital-based registry (the European Community Stroke Project). Stroke 2001; 32:392-8.

12. Winter Y, Wolfram C, Schaeg M, et al. Evaluation of costs and outcome in cardioembolic stroke or TIA. J Neurol 2009; 256:954-63.

13. Jorgensen HS, Nakayama H, Reith J, et al. Acute stroke with atrial fibrillation. The Copenhagen Stroke Study. Stroke 1996; 27:1765-9.

14. Stroke Risk in Atrial FibrillationWorking Group. Independent predictors of stroke in patients with atrial fibrillation: a systematic review. Neurology.2007; 69(6):546-554.

15. Pisters R, Lane DA, Marin F, Camm AJ, Lip GY. Stroke and thromboembolism in atrial fibrillation. Circ J. 2012; 76(10):2289-2304.

16. Lip GY, Lane DA. Stroke prevention in atrial fibrillation: a systematic review. JAMA. 2015; 313(19):1950-62

17. ESC 2010 - The Task Force for the Management of Atrial Fibrillation of the European Society of Cardiology (ESC). Guidelines for the management of atrial fibrillation. European Heart Journal 2010; 31(19): 2369-2429.

18. Lip GY. Stroke and bleeding risk assessment in atrial fibrillation: when, how, and why? Eur Heart J.2013; 34(14):10411049.

19. Padjen V, Jovanovic DR, Leys D et al. Predicting the outcomes of acute ischaemic stroke in atrial fibrillation: the role of baseline CHADS2, CHA2DS2-VASC and HASBLED score values. Acta Cardiol. 2013; 68(6):590-6.

20. Olesen JB, Torp-Pedersen C, Hansen ML, Lip GY. The value of the CHA2DS2-VASc score for refining stroke risk stratification in patients with atrial fibrillation with a CHADS2 score 0-1: a nationwide cohort study. Thromb Haemost. 2012; 107(6):1172-1179.

21. ZhuW-G, Xiong Q-M, Hong K.Meta-Analysis of CHADS2 versus CHA2DS2-VASc for predicting stroke and throm- boembolism in atrial fibrillation patients independent of anticoagulation. Tex Heart Inst J. 2015; 42(1):6-15.

22. Lip GY, Andreotti F, Fauchier L, et al; European Heart Rhythm Association. Bleeding risk assessment and management in atrial fibrillation patients. Executive Summary of a Position Document from the European Heart Rhythm Association [EHRA], endorsed by the European Society of Cardiology [ESC]Working Group on Thrombosis. Thromb Haemost. 2011; 106(6):997-1011.

23. Omran H, Bauersachs R, Rübenacker S, Goss F, Hammerstingl C. The HAS-BLED score predicts bleedings during bridging of chronic oral anticoagulation: results from the national multicentre BNK Online Bridging Registry (BORDER). Thromb Haemost. 2012; 108(1):65-73.

24. Wegscheider K, Boriani G, Brandes A, Ezekowitz M, Diener $\mathrm{H}$, Haegeli $\mathrm{L}$, et al. Comprehensive risk reduction in patients with atrial fibrillation: Emerging diagnostic and therapeutic options. Executive summary of the report from the 3rd AFNET/EHRA consensus conference. Europace $2012 ; 14: 8-27$

25. Fuster V, Ryden LE, Cannon DS, et al. ACC/AHA/ESC 2006 Guidelines for the management of patients with atrial fibrillation: a report of the American College of Cardiology/American Heart Association Task Force on Practice Guidelines and the European Society of Cardiology Committee for Practice Guidelines (Writing Committee to Revise the 2001 Guidelines for the Management of Patients With Atrial Fibrillation): developed in collaboration with the European Hearth Rhythm Association and the Hearth Rhythm Society. Circulation 2006; 114:e257-e354.

26. Kirchhof P, Auricchio A, Bax J, et al. Outcome parameters for trials in atrial fibrillation: recommendations from a consensus conference organized by the German Atrial Fibrillation Competence NETwork and the European Heart Rhythm Association. Europace 2007; 9:1006-23.

27. Camm AJ, Lip GY, De Caterina R, et al; ESC Committee for Practice Guidelines-CPG; Document Reviewers. 2012 focused update of the ESC Guidelines for the management of atrial fibrillation: an update of the 2010 ESC Guidelines for the management of atrial fibrillation. Europace. 2012; 14(10):1385-1413.

28. US 2009 - Aspirin for the prevention of cardiovascular disease: U.S Preventive Services Task Force recommendation statement. Ann Inter Med. 2009; 150:396-404.

29. van Walraven C, Hart RG, Singer DE, et al. Oral anticoagulants vs. aspirin in nonvalvular atrial fibrillation: an individual patient meta-analysis. JAMA 2002; 288:2441-8.

30. Bungard TJ, Ghali WA, Teo KK, et al. Why do patients with atrial fibrillation not receive warfarin? Arch Intern Med 2000; 160:41-6.

31. McBride D, Bruggenjurgen B, Roll S, et al. Anticoagulation treatment for the reduction of stroke in atrial fibrillation: a cohort study to examine the gap between guidelines and routine medical practice. J Throm Thrombolysis. 2007; 24:65-72.

32. Hacke W, Kaste M, Bluhmki E, et al. Thrombolysis with alteplase 3 to 4.5 hours after acute ischemic stroke. N Engl J Med 2008; 359:1317-1329.

33. Lees KR, Bluhmki E, von Kummer R, et al. Time to treatment with intravenous alteplase and outcome in stroke: an 
updated pooled analysis of ECASS, ATLANTIS, NINDS, and EPITHET trials. Lancet 2010; 375:1695-1703.

34. Hacke W, Kaste M, Bogousslavsky J, et al. European Stroke Initiative Recommendations for Stroke Management-update 2003. Cerebrovasc Dis 2003; 16:311-37.

35. Sacco RL, Adams R, Albers G, et al. Guidelines for prevention of stroke in patients with ischemic stroke or transient ischemic attack: a statement for healthcare professionals from the American Heart Association/American Stroke Association Council on Stroke: co-sponsored by the Council on Cardiovascular Radiology and Intervention: the American Academy of Neurology affirms the value of this guideline. Stroke 2006; 37:577-617.

36. Schwamm LH, Pancioli A, Acker JEr, et al. Recommendations for the establishment of stroke systems of care: recommendations from the American Stroke Association's Task Force on the Development of Stroke Systems. Stroke $2005 ; 36: 690-703$.

37. The National Institute of Neurological Disorders and Stroke rt-PA Stroke Study Group: Tissue plasminogen activator for acute ischemic stroke. N Engl J Med 1995; 333:1581-1587.

38. Adams HP Jr, del Zoppo G, Alberts MJ, et al. Guidelines for the early management of adults with ischemic stroke: a guideline from the American Heart Association/American Stroke Association Stroke Council, Clinical Cardiology Council, Cardiovascular Radiology and Intervention Council, and the Atherosclerotic Peripheral Vascular Disease and Quality of Care Outcomes in Research Interdisciplinary Working Groups: the American Academy of Neurology affirms the value of this guideline as an educational tool for neurologists. Stroke 2007; 38(5):1655-1711.

39. Furie KL, Goldstein LB, Albers GW, et al. Oral Antithrombotic Agents for the Prevention of Stroke in Nonvavular Atrial Fibrillation: A Science Advisory for Healthcare Professionals From the American Heart Association/American Stroke Association. Stroke 2012; 43(12):3442-53.

40. Bluhmki E, Chamorro A, Davalos A, et al. Stroke treatment with alteplase given 3.0-4.5 h after onset of acute ischaemic stroke (ECASS III): additional outcomes and subgroup analysis of a randomised controlled trial. Lancet Neurol 2009; 8(12):1095-1102.

41. Sandercock P, Wardlaw JM, Lindley RI, et al. The benefits and harms of intravenous thrombolysis with recombinant tissue plasminogen activator within $6 \mathrm{~h}$ of acute ischaemic stroke (the third international stroke trial [IST-3]): a randomised controlled trial. Lancet 2012; b379:2352-2363.

42. Generalized efficacy of t-PA for acute stroke. Subgroup analysis of the NINDS t-PA Stroke Trial. Stroke 1997; 28:2119-2125.
43. Frank B, Fulton R, Weimar C, et al. Impact of atrial fibrillation on outcome in thrombolyzed patients with stroke: evidence from the Virtual International Stroke Trials Archive (VISTA). Stroke 2012; 43:1872-1877.

44. Zhang JB, Ding ZY, Yang Y, et al. Thrombolysis with alteplase for acute ischemic stroke patients with atrial fibrillation. Neurol Res 2010; 32:353-358.

45. Padjen V, Jovanovic D, Berisavac I, et al. Effect of intravenous thrombolysis on stroke associated with atrial fibrillation. J Stroke Cerebrovasc Dis. 2014; 23(8):2199-205.

46. Padjen V, Bodenant M, Jovanovic DR, et al. Outcome of patients with atrial fibrillation after intravenous thrombolysis for cerebral ischaemia. J Neurol. 2013; 260(12):3049-54.

47. Xian Y, Liang L, Smith E, et al. Risks of intracranial haemorrhage among patients with acute ischemic stroke receiving warfarin and treated with intravenous tissue plasminogen activator. JAMA 2012; 307: 2600-2608.

48. Vergouwen MD, Casaubon LK, Swartz RH, et al; Investigators of the Registry of the Canadian Stroke Network. Subtherapeutic warfarin is not associated with increased hemorrhage rates in ischemic strokes treated with tissue plasminogen activator. Stroke 2011; 42:1041-1045.

49. Kim YD, Lee JH, Jung YH, et al. Safety and outcome after thrombolytic treatment in ischemic stroke patients with high-risk cardioembolic sources and prior subtherapeutic warfarin use. J Neurol Sci 2010; 298:101-105.

50. Meretoja A, Putaala J, Tatlisumak T et al. Off-label thrombolysis is not associated with poor outcome in patients with stroke. Stroke 2010; 41:1450-1458.

51. Seet RC, Zhang Y, Moore SA, et al. Subtherapeutic international normalized ratio in warfarin-treated patients increases the risk for symptomatic intracerebral hemorrhage after intravenous thrombolysis. Stroke 2011; 42:23332335.

52. Ruecker M, Matosevic B, Willeit P, et al. Subtherapeutic warfarin therapy entails an increased bleeding risk after stroke thrombolysis. Neurology 2012; 79:31-38.

53. Prabhakaran S, Rivolta J, Vieira JR, et al. Symptomatic intracerebral hemorrhage among eligible warfarin-treated patients receiving intravenous tissue plasminogen activator for acute ischemic stroke. Arch Neurol 2010; 67:559563.

54. Miedema I, Luijckx GJ, De Keyser J, et al. Thrombolytic therapy for ischaemic stroke in patients usingwarfarin: a systematic review and meta-analysis. J Neurol Neu-rosurg Psychiatry 2012; 83:537-540.

55. Hankey GJ, Norrving B, Hacke W, et al. Management of acute stroke in patients taking novel oral anticoagulants. Int J Stroke. 2014; 9 (5):627-31. 